\title{
Uveal Melanoma Clinical Distant Metastasis TNM Finding v8
}

National Cancer Institute

\section{Source}

National Cancer Institute. Uveal Melanoma Clinical Distant Metastasis TNM Finding v8. NCI Thesaurus. Code C140605.

A clinical finding about one or more characteristics of uveal melanoma, following the rules of the TNM AJCC V8 classification system as they pertain to distant metastases. 